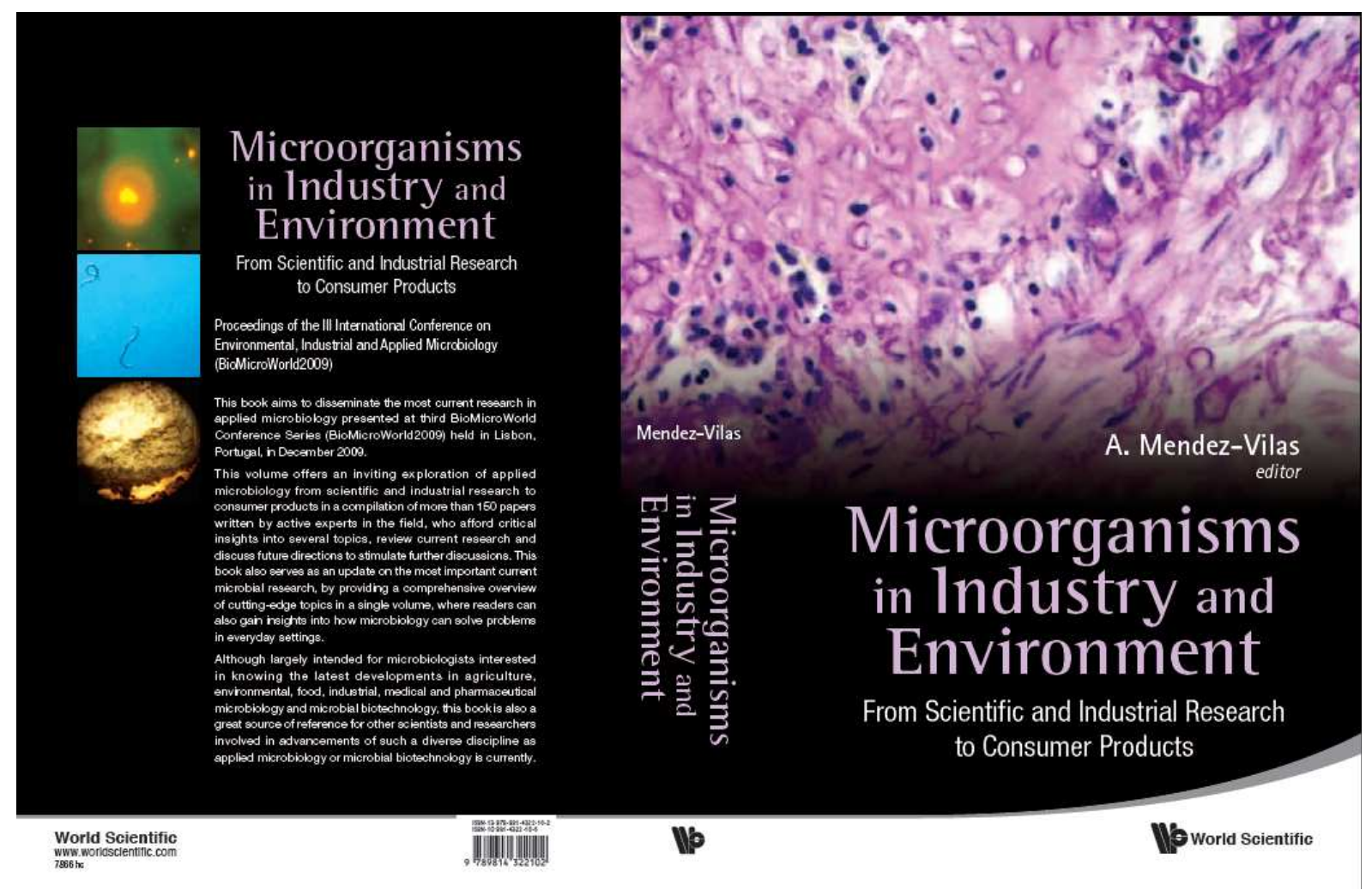

\title{
Vanadium pentoxide: an oxidative stress agent which disturbs glutathione conjugates metabolization in Saccharomyces cerevisiae $\mathrm{UE}_{\mathbf{H}} \mathrm{ME}_{3}$
}

\author{
S. Gonçalves ${ }^{1}$, I. Alves-Pereira ${ }^{1,2}$ and R. Ferreira ${ }^{*}, 1,2$ \\ ${ }^{1}$ Departamento de Química, Escola de Ciências e Tecnologia, Universidade de Évora, R. Romão Ramalho, 59 \\ 7002-554 Évora, Portugal \\ ${ }^{2}$ Instituto de Ciências Agrárias e Ambientais Mediterrânicas, Centro de Tecnologia Animal (ICAAM-CTA), \\ Universidade de Évora, Núcleo da Mitra, Apartado 94, 7002-774 Évora, Portugal
}

\begin{abstract}
Under physiological conditions the vanadium can be detected in the oxidation state $\mathrm{V}(+5)$, a very toxic specie. In this study we used a wine wild-type Saccharomyces cerevisiae $\mathrm{UE}^{-\mathrm{ME}_{3}}$ to assess how eukaryotic cells respond to $\mathrm{V}_{2} \mathrm{O}_{5}$. Yeast cells in exponential phase were inoculated into YEPD medium with $2 \%(\mathrm{w} / \mathrm{v})$ glucose and allowed to grow in the absence or presence of 0.5 to $2.0 \mathrm{mM} \mathrm{V} \mathrm{O}_{5}$ during $72 \mathrm{~h}$. The results show that the cellular environment became more oxidizing, cell damages increase and failures in the transport and excretion of amino acids to the vacuole ocurr in yeast cells grown in the presence of vanadium $(+5)$, as can be inferred by the decrease of GSH/GSSG ratio, increase of MDA cytoplasmic level and the sharp decrease of $\gamma$-GT activity observed. Although there was an apparent response anti-stress to $\mathrm{V}_{2} \mathrm{O}_{5}$, reflected in an increase of GR activity in all trials of metal exposure and of GPx in cells exposed to 1.5 and $2.0 \mathrm{mM}$, this was probably mitigated by the decrease in activity G6PD and consequent availability of NADPH which compromise cell viability.
\end{abstract}

Keywords Saccharomyces cerevisiae, vanadium pentoxide; oxidative stress

* Corresponding author: e-mail: raf@uevora.pt, Phone: +351266745300 